\title{
Dat die klip kan heers: Pieter Fourie se Die koggelaar
}

\begin{abstract}
Die koggelaar (The teaser), by playwright Picter Fourie, is generally regarded as exceptional among his recent works. The purpose of this article is to discuss the title and drought as recurring themes in the drama. The teaser is Boet Cronje, but he is of the opinion that everyone teases him. In an ironic twist of events he finally believes that God teases him by not providing the rain he so desperately needs.

An investigation of the text reveals the utilization of psychoanalytical theory, i.e. the theory of the collective and the personal unconscious as formulated by Jung. In this case physical drought initiates events which lead to the development of a fully-fledged psychosis in Boet. As a consequence of the interconnection of the personal and the collective unconscious the physical drought surrounding Boet additionally becomes a dramatic metaphor for the figurative drought in the community of which he is part.
\end{abstract}

\section{Inleidend}

Die koggelaar is, soos op bladsy 61 van die gepubliseerde teks vermeld word, in 1986 voltooi. Die drama word in daardie selfde jaar met die SAKRUK-prys bekroon, en in 1987 met die DALRO-prys. SUKOVS sou aanvanklik die SAKRUK-produksie van die teks onderneem, mar die opvoering word gekanselleer. Die eerste opvoering is uiteindelik in 1987 onder regie van Dieter Reible.

Nieteenstaande die moontlike negatiewe indruk wat die aanvanklike kansellasie mag skep, het resensente hulle meestal positief oor die drama uitgelaat. So skryf Barrie Hough (1988:44-45), onder die opskrif "Fourie se drama is meesterlik", dat dit "'n meesterwerk (is) wat gekenmerk word deur ekonomie, 'n hegte struktuur, 'n sterk emosionele inslag en van die rykste taal in die Afrikaanse drama". Hy sluit sy bespreking met hierdie waardeoordeel af: "Met Die koggelaar lewer Fourie een van die beduidenste (sic) bydraes nog tot die skrale Afrikaanse dramaliteratuur."

Soos Hough noem Peet van Rensburg (1989:123-125) 'n aantal sake, waarmee meestal saamgestem kan word. Volgens Van Rensburg is Boet "'n vol karakter met lewensbloed wat skree om meersterlik (sic) op die Afrikaanse verhoog gespeel te word", is Die koggelaar "'n volwaardige speelbare toneelstuk", en spreek "die dialoog en netjiese, kernagtige tonele in 'n boeiende struktuur" van die teks se toneelmatigheid. Hy sluit sy bespreking af met die woorde: "Met hierdie stuk het Fourie onteenseglik bewys gelewer dat hy tans Suid-Afrika se Afrikaanse toneelskrywer par excellence is." 
In teenstelling met bostaande uitsprake is Schutte (1989:76-88) meer krities. Hy skryf dat "(d)ie spanning ... deurgaans behou (word) totdat Boet se lewe in al sy aanmatiging en skuld oopgevlek is. Simpatie vir hom word nie gewek nie, maar wel skrik. Van ware selfkennis is daar dan ook nie sprake nie". Hy vervolg: "Die rasse-element word te opsetlik ingevoer om die handeling tot 'n slotsom te kan bring."

Tematies het die verband tussen Die koggelaar en 'n vorige drama deur Fourie, Ek, Anna van Wyk, opgeval. In hierdie verband skryf Hough (1988:44-45): "Soos Ek, Anna van Wyk is Die koggelaar 'n aanklag teen chauvinisme en rassisme. Die Afrikaner-patriarg se houdings word skerp aangeval, maar hy word nietemin met deernis uitgebeeld. Hier is 'n dramaturg wat met insig en ewewig en bowenal 'n liefde vir Suid-Afrika en sy probleme skryf."

'n Vergelyking van die vermelde resepsieverslae laat enkele verskille blyk. So staan Hough se woorde, "(h)ier is 'n dramaturg wat met ... ewewig ... skryf", naas Schutte se beswaar dat "(d)ie rasse-element ... te opsetlik ingevoer (word) om die handeling tot 'n slotsom te kan bring". Verder staan Schutte se beswaar, dat daar by Boet nie van selfkennis sprake is nie, naas Van Rensburg se opmerking dat Boet 'n "vol figuur" is.

Teen die agtergrond van die beperking op die lengte van die geraadpleegde resensies - en die kriptiese uiteensetting wat dikwels met resensieskryf saamgaan - wil dit gevolglik voorkom of ' $n$ vollediger bespreking van, soos Hough dit bo stel, "een van die beduidenste (sic) bydraes nog tot die skrale Afrikaanse dramaliteratuur", aangewese is. Met inagneming van die breë riglyne wat die vermelde resensies verskaf, val die fokus van die bespreking op die titel en droogte as tema.

\section{Boet Cronjé: koggelaar}

Die koggelaar, waarna die titel van die drama verwys, is Boet Cronjé. Later vind daar, vanuit Boet se perspektief, ' $n$ ironiese ommekeer plaas as hy God, in sy gebed tydens die biddag vir reën, die koggelaar noem (bladsy 42, onder). Sy aanvanklike verhouding met God was 'normaal'. Daarmee word bedoel dat sy religieuse houding in ooreenstemming was met wat die gemeenskap as aanvaarbaar beskou. Dit blyk onder andere uit sy woorde aan Knaplat op bladsy 4:

\footnotetext{
Ja ... hy was my God. As jy boer, is jy en jou God saam. Dis 'n persoonlike ding. Hy's soos jou bankbestuurder, 'n soort vennoot, 'n vertroueling ... Dis 'n snaakse ding, maar dis anders. Jou verhouding met God is anders as dié van 'n dorpenaar of stedeling.
}

Die opvatting dat die boer, in sy afhanklikheid van die elemente en die bodem, in 'n besondere verhouding tot God staan, kom algemeen in die boerderygemeenskap voor. Boet sê dus hier wat 'n mens van hom kan verwag.

Tog is daar op bladsy 5 tekens dat hierdie verhouding nie suiwer is nie. Daar is die aanduiding van hovaardigheid in sy mening dat die "swartetjies" van die werf moet af omdat hul teenwoordigheid "hans" sou wees. Verder is daar die aanduiding dat hy teen Anna se ouers se wens met haar getrou het. Die duidelikste teken van 'n skewe verhouding met God, op bladsy 5, is sy mening dat, "(a)s jy God nie inneem as vennoot nie, kan jy maar vergeet van boer". Tereg herken Anna in hom die aartssonde van trots, maar vervul dit haar, ironies, met bewondering. 
Voorlopig gaan dit dus met Boet en sy huwelik goed. Dit word weerspieël in die geboorte van Klein-Ben. Ook die verhouding met God verloop oënskynlik seepglad - 'n indruk wat tydens Daan Diaken se besoek, om te groet nadat hy uitgeboer het, versterk word. Maar wanneer 'n verbitterde Daan Boet se geloof en die troos van die Bybel verwerp, slaan Boet hom plat (bladsy 11). In plaas van om die ander wang te draai, neem hy die reg in eie hande. Ook hieruit spreek trots. Vergelyk sy woorde op bladsy 9: "Die lang en verskriklike droogte het gekom. God het ons geslaan, beproef en verlaat. Maar toe ander rondom my dwaal, het ek vasgetrap. Sterk in my geloof bly staan." Die droogte, wat later in die handelingsverloop 'n oorheersende rol sal vervul, kom nou in die spel.

Die beeld wat tot hier van Boet geteken word, is tradisioneel. Hy is verteenwoordigend van die Afrikaanse boer, met ander woorde hy besit 'n plaas, het 'n erfgenaam en is 'n steunpilaar in die instituut, die kerk. Of Boet verteenwoordiger is van die Afrikaner vereis egter verdere kwalifikasie. Indien die konteks van die situasie (of: makrokonteks - Elam, 1980:137) in aanmerking geneem word, is dit duidelik dat die dramaturg swaar steun op geykte opvattings (meestersimbole) in verband met die Afrikaner. ${ }^{1}$ Vergelyk, in hierdie bespreking, die uiteensetting (onder) van die verband tussen die kode droogte en die onderbewuste.

Indien die huidige konteks van die situasie in ag geneem word, skyn dit asof die inhoud van meestersimbole in die Afrikaanse gemeenskap besig is om 'n verskuiwing te ondergaan. Daarvan spreek veral die kerklike en politieke woelinge van die afgelope aantal jare. Dat die konteks van die situasie wel 'n invloed op die dramawerklikheid gehad het, blyk uit Boet se veranderde houding teenoor Anker wanneer hy die geleentheid kry om sy selfmoord te verduidelik. Om te beweer dat daar by Boet geen sprake van selfinsig is nie, is dus nie korrek nie. Lees hiermee saam die suggestie van selfinsig in sy woorde op bladsy 60: "Jou koggelaar! ... Waarom so stil? Waarom? Is dit dan ek? Is ék die droogte?" (my kursivering - JLC).

Ook die boorgattoneel (bladsy 18 en verder) dien as 'n illustrasie van Boet se hovaardigheid. Dit is opmerklik hoe terughoudend hy is oor die vonds van die water in vergelyking met die byna ekstatiese blydskap van Klein-Ben, Ben, Arker en Betta. Hierdie gegewe moet saamgelees word met Ben se belewenis van die vonds. Vir hom is dit "die diepte van die Here se genade" (bladsy 16), 'n ingesteldheid wat strook met die inhoud van sy en Anker se gebed op bladsy 14. By daardie selfde geleentheid bid Boet egter dat hy "nie knak soos Daan nie". In sy gebed gaan dit nie vir hom om die droogte nie, maar om die behoud van sy trots.

\footnotetext{
${ }^{1}$ Du Preez (in Muller et al., 1989:13) omskryf 'n meestersimbool as "'n simboliese becld wat so diep in die waardesisteem van sy aanhanger ingegrif is, dat hy dit as 'n vanselfsprekende feit aanvaar". Van die meestersimbole, wat sy na aanleiding van 'n studie van skoolhandboeke aflei, is dat wettige gesag nie bevraagteken word nie, dat blankes meerderwaardig is en swartes minderwaardig, dat die Afrikaner 'n spesiale verbouding met God het, dat Suid-Afrika die Afrikaner se land is, dat SuidAfrika 'n landbouland is, dat die Afrikaner 'n boerevolk is, ensovoorts. Verskeie van hierdie meestersimbole is in die konteks van die uiting van die drama (Elam, 1980:137-138) werksaam. Daar is, as voorbeeld, in die bespreking reeds verwys na Boet se gewaande spesiale verbouding met God.
} 
Dit is tydens die boorgattoneel, dit wil sê die tyd-van-die-terugflits, ${ }^{2}$ dat die droogte 'n metafisiese aard verkry. Op bladsy 19 sê Ben: "Tradisie het dit dat die eerste ou watertjie ... bruin, modderig soos hy is ... saam hier in die glas moet in. Dan besweer hy die bose met God's gawe" (my kursivering - JLC). Daar kom in sy woorde 'n parallelisme voor: soos die boorgat se water (God se gawe) die fisiese droogte sal bestry, bestry God die bose. Met behulp van die parallelisme word die droogte gelykgestel met die bose. Boet kan die droogte besweer deur die wateraar verder oop te boor, maar hy weier om dit na Klein-Ben se dood te doen.

Hy weier dus, hardkoppig en trots, om die bose 'droogte' te besweer. Daardeur tree die droogte in hom al sterker op die voorgrond, onder andere in sy opstand teen God. Hy beleef God as iemand wat nie aan sy wens wil voldoen nie: Hy wil nie laat reën waar Boet wil nie, en daarom skiet Boet na die wolke sodat Hy kan sien waar dit moet reën (bladsy 41). Later kalk hy selfs die droë dambodem vir dieselfde doel wit (bladsy 60). In sy hardnekkige trots ervaar Boet God as iemand wat hom uittart, wat hom 'koggel' (bladsy 36).

Van hier af vertoon die handelingsverloop 'n patroon van eb en vloed. Boet word deur die droogte geobsedeer, tot so 'n mate dat dit vir hom voorkom of nie net God nie, maar almal om hom sy vyand is (bladsy 44). Hy hou God verantwoordelik vir die droogte en beskuldig Hom, tydens die biddag vir reën, daarvan dat Hy besig is om 'n bespotting van sy huwelik te maak (bladsy 42). As Anna in haar swartgekleurde trourok in die kerk verskyn, vra hy of sy hom ook kom koggel. Sy het die rok so gekleur as 'n teken van rou oor die verbrokkeling van hul huwelik.

Boet ondergaan skynbaar ' $n$ verandering wanneer Anker hom oorhaal om die wateraar oop te boor (bladsy 44 tot 46). Maar nog het sy trots hom nie verlaat nie, soos sy woorde, "Maar ek is Boet Cronjé", laat blyk. ${ }^{3}$ Die gevolg is dat die vloed van waansin (bladsy 56: "Die kind is mal") terugkeer, en selfs as gevolg van Klein-Ben se droom-tipe verskynings aangroei. Anker beskryf die klimaks van dié waan op bladsy 55: "Alles, almal koggel jou glo. Maar jy ... jy is die groot koggelaar! Jy wil God speel!" (my kursivering - JLC).

\footnotetext{
2 Om hier bloot van die gespeelde tyd te praat is onpresies, onder andere as gevolg van die metadramatiese aard van die teks. Een verskyningsvorm van daardie aard is die veelvlakkigheid van die "gespeelde tyd". Een van die vlakke is die tyd waaruit Knaplat as 'n tipe verteller optree (bladsy 1 en daarby aanvullend, bladsy 61). Daarby kan gevoeg word die tyd-van-die-tenuglits. Met hierdie term word verwys na die tyd wat betrokke is by die voorstelling van Boet se poging om sy selfmoord te verduidelik. In hierdie tyd kom daar dan nog verdere vlakke (terugflitse) voor, wat nog verder in die tyd teruglê. 'n Voorbeeld is die kroegtoneel (bladsy 25 en verder) wat, in Boet se eie woorde, afspeel toe hy "nog 'n student" was, "gedurende cen Julievakansic". Die gemak waarmee die handeling van een tydvlak na die volgende beweeg is in 'n hoe mate te danke aan die rol wat Knaplat (onder andere) as 'n tipe verteller vervul. Dit bring mee dat die handelingsverloop episodies vertoon. Ook in hierdie opsig is daar dus ooreenkomste tussen Die koggelaar en die epiese drama.
}

${ }^{3}$ Hierdie woorde herinner aan Bart Nel se "Ek is Bart Nel van toe af, en ek is nog hy" (Van Melle, 1977:199). Selfs Boet se woorde op bladsy 44 ("My grond, my God, my vrou - almal het my verlaat") herinner aan Bart Nel. Die verskille tussen Die koggelaar en Ban Nel is egter te groot om van direkte beinvloeding te praat. Binne die breè verband van die Afrikaanse letterkunde is daar ook ingrypende verskille tussen hierdie twee werke, wat onder andere die voorstelling van seksualiteit betref. Ook ander werke in Afrikaans tril in hierdie dramateks na, onder andere Fourie se eie Ek, Anna van Wyk (Boet se vrou is ook 'n Anna!), Bartho Smit se Bacchus in die Boland, Van Wyk Louw se Berei in die woestyn (1970), Die Bybel en Van Heerden se Toorberg. Die titel van hierdie bespreking is ontleen aan Berei in die woestyn. 
Daar is in die slottoneel die suggestie dat Boet voor sy selfmoord tot insig kom. Vir hom is dit egter te laat: hy móet van die toneel verdwyn sodat die reën, die gawe wat die droogte moet besweer, kan uitsak (bladsy 61 en bladsy 2 ). ${ }^{4}$

\section{3. 'n Verklaring vir Boet se optrede}

Die vraag is hoe Boet se eb en vloed van waansin verklaar kan word. Myns insiens bied Jung se teorie ë 'n aanduiding van 'n verklaring. Dat Jung in 'n verklaring meespreek, blyk uit Knaplat se woorde (bladsy 51):

BOET: ... Dit was Klein-Ben.

KNAPLAT: Het jy nie maar gedroom nie?

BOET: Nee.

KNAPLAT: Jou gewete dalk? (Pouse) Jou vrese?

BOET: Nee. Dit was Klein-Ben.

(My kursivering JLC.)

Boet se fisiese omstandighede was die sneller wat sy obsessie met die droogte, en uiteindelik met God as koggelaar, aan die gang gesit het. Dit het tot 'n bose kringloop gelei: hoe langer die droogte geduur het, hoe groter het sy obsessies geword totdat dit 'n vorm van psigose was (Fordham, 1975:147). ${ }^{5}$ Uiteindelik het die droogte van sy gees besit geneem. Vergelyk Anker se treffende insig op bladsy 54:

Dis nie dat dit só droog is nie. Meneer moet net met minder tevrede wees. Verminder die skaap met die helfte, boor die aar oop, laat Knaplat rus ... Meneer wil net ontvang, maar niks gee nie

Meneer, die droogte van die veld is daar soos die getye van die maan. Maar as jy droog is in jouself, jou kop, jou hart, jou hande ... as jy in dié droogte is, meneer, dan is jy in jou vrekte. Vir die droogte bid jy nie net nie. Jy sorg vir jou eie reën. Sorg jy nie self nie, sorg niemand nie. Vrek jy net binne in jouself.

Daar is gevolglik ruimte vir die afleiding dat die droogte ' $n$ groot hoeveelheid psigiese energie, of libido (Fordham, 1975:17), in Boet ontketen het. Die natuurlike beweging van libido het, volgens Jung, die aard van die see se eb en vloed. Sou daar'n besonder groot obstruksie in die weg van die beweging van die libido te lande kom, kan dit tot 'n uitbarsting lei of 'n psigose mag ontstaan (Fordham, 1975:19). In die geval van Boet was daar eers verskeie uitbarstings, wat in die teks die vorm neem van onder andere die skiet na die wolke.

Omdat dit nie gereën het nie, is die obstruksie nie verwyder nie. Die gevolg was dat Boet se psigiese energie oorgedra is "to something similar in nature to the object of instinctive interest" (Fordham, 1975:19). Laasgenoemde is in die drama God, omdat Hy, vanuit Boet se religieuse belewenis, reën kan voorsien. Dit word bevestig deurdat Boet, ten spyte daarvan dat hy die afwesigheid van reën as God se gekoggel ervaar, tog die biddag vir reën

\footnotetext{
${ }^{4}$ Kyk my interpretasie van die slottoneel in 7.

${ }^{5}$ My toepassing van Jung se psigologie vervolgens aan die hand van Fordham (1975). Omdat die volledige inhoud van Jung se opvaltings buite die veld van hierdie bespreking le, gaan ek nie in besonderhede daarin op nie. Dit sluit onder andere die aard ván, en die verhouding tússen, libido, die persoonlike en die kollektiewe onderbewuste in.
} 
bywoon. Nog word die obstruksie nie verwyder nie, met die gevolg dat daar in sy persoonlikheid 'n simbool ontstaan (Fordham, 1975:19):

The direction of energy becomes initially possible by transferring it to something similar in nature to the object of instinctive interest. ... After a period of gestation in the unconscious a symbol is produced which can attract the libido, and also serve as a channel diverting its natural flow.

In die teks neem die simbool die vorm aan van Klein-Ben in droom-tipe verskynings. Hy sê elke keer min of meer dieselfde ding, byvoorbeeld op bladsy 52:

Pa moet nooit die aar oopboor nie. Nooit nie. Daar is bloed in die water. Pa moet God aanspreek, uitdaag. Hy moet water stuur. Hy't my gevat. Hy't Pa se tiende gevat. Nou wil hy die diere vat, die plaas, alles.

As gevolg van hierdie konteks van die uiting groei Klein-Ben as die toneelmatige voorstelling van Boet se trots en hardnekkigheid. Sy funksie is om, as ' $n$ verskyningsvorm van Boet se onderbewuste, ${ }^{6}$ daardie trots en hardnekkigheid te versterk. Laasgenoemde lei tot ondergang wanneer Boet sy eie lewe neem.

Hierdie verwysing na die invloed wat Boet se persoonlike onderbewuste op sy ego ${ }^{7}$ uitoefen, vestig die aandag op die verband wat Jung tussen die persoonlike en die kollektiewe onderbewuste le (Fordham, 1975:23). Die kollektiewe onderbewuste is ' $n$ dieper vlak van die onderbewuste en bestaan uit, soos Fordham (1975:146) dit beskryf, "psychic contents which are nog common to one individual, but to many".

Op grond van bostaande verduideliking kan nou afgelei word dat Boet se obsessie met die droogte die dramaturg se metaforiese stelwyse is vir uitbarstings van die libido in die hoofkarakter se persoonlike onderbewuste. As gevolg van die verbintenis tussen die persoonlike en kollektiewe onderbewuste is sy 'droogte' egter ook die 'droogte' van die gemeenskap waarin hy bestaan.

\section{Aard van die droogtes}

Daar is in Die koggelaar sprake van verskeie (abstrakte) droogtes in Boet se persoonlike lewe, en op die vlak van die gemeenskap. Die implikasie daarvan is dat nie net Boet nie, maar ook die gemeenskap God se koggelaar is. Gemeen aan al die droogtes is dat hulle sleg, of "boos" (vergelyk bladsy 19), is. So word daar aan droogte 'n abstrakte, of metafisiese, betekenis toegeken: Boet se 'droogtes' word die 'droogtes' van almal wat met hom saamleef. As voorbeelde geld die droogte in Boet se huwelik (onder andere die droogte van kinderloosheid) en die droogte van swak menseverhoudinge (op die vlak van die gemeenskap). Die fisiese droogte om Boet het dus 'n metaforiese (of: allegoriese) ${ }^{8}$ korrelaat wat homself en sy omgewing 'besmet'.

\footnotetext{
${ }^{6}$ In hierdie stadium het Boet se obsessic in 'n volwaardige psigose oorgegaan. Vergelyk Fordham (1975:147) se omskrywing van 'n psigose: "... the invasion of the conscious by unconscious contents, so that the ego is partially or completely overwhelmed. What is commonly known as insanity ... ".

${ }^{7}$ Fordham (1975:146): "the centre of the conscious mind".

${ }^{8}$ Ook die Verklarende Afrikaanse Woordeboek (1972, s.v. allegorie) gee die woord allegorie aan as 'n "uitgewerkte metafoor".
} 
Honig (1982:114) skryf oor die verband tussen die metafoor en die allegorie onder andere dat "( $\mathrm{t}$ he assumption here is that analogy, irony, and dialectic transfer are distinctive verbal modes in allegory".9 Die aanhaling dui die wyses aan waarop die 'bose besmetting' van die droogtes uit sy omgewing op Boet en op die persone om hom oorgedra word. In die dramateks neem dit die vorm aan van die misbruik van die natuur (oorbenutting van Knaplat), die miskenning van sy medemens se wense (Anna se ouers in verband met hulle huwelik) en gevoelens (Anker tydens die kroegtoneel), die verwerping van veral Anna, en uiteindelik 'n familiemoord waarin hy homself, Ben, Betta en Anna om die lewe bring (bladsy 59). Genoemde 'besmetting' het in die dramateks dus die aard van iets negatief, en dit beïnvloed al die verhoudings waarby Boet betrokke is. ${ }^{10}$

Ten opsigte van verhoudings met die gemeenskap waarin Boet bestaan, word vervolgens veral op die kroegtoneel gelet. Die kroegtoneel is uitgesonder as gevolg van die prominensie wat dit geniet op grond van die getal bladsye wat in die dramateks daaraan afgestaan word.

\subsection{Gemeenskap}

'n Kenmerk van Die koggelaar is dat dit, teen die agtergrond van die konteks van die situasie, aktueel wil wees. Wat die voorstelling van die handeling betref, wentel dié aktualiteit veral om Anker. Die dramaturg maak van hom 'n verhoogmetafoor, byna 'n soort allegoriese personasie. Anker versinnebeeld die kollektiewe droogte in die gemeenskap ten opsigte van bepaalde aspekte. In die drama kom veral ras en kJeur ter sprake.

Hierdie opset bring mee dat Die koggelaar betrokke drama is. Gevolglik is dit onderworpe aán dié groot beperking op alle betrokke dramas, naamlik sy tydgebondenheid. Sou die aktuele saak sy slaankrag verloor, verloor die drama sy trefkrag. Gegewe die veranderinge wat tans in die Suid-Afrikaanse gemeenskap plaasvind, wil dit voorkom of veral die drama se uitbeelding van rassediskriminasie vorentoe sy trefkrag $\mathrm{kan} / \mathrm{mag}$ verloor. In hierdie verband kan veral op die kroegtoneel gelet word. Om vas te stel of die kroegtoneel binne die verloopsplan val, moet vasgestel word of dit 'n funksionele onderdeel van die drama is.

Tydens die kroegtoneel val die onmenswaardige behandeling van Anker op. Sy gevoelens word nie in aanmerking geneem nie - nie ten opsigte van die manier waarop hy behandel word of ten opsigte van wat aan (en: van) hom gesê word nie. In die koudste van Karoowinternagte moet hy agter op die bakkie dorp toe ry, kan in 'n onsinnige weddenskap ' $n$ maand se salaris 'verdien', moet in die kroeg skeldtaal teen homself gebruik en, in 'n bizarre hoogtepunt, sy mond oopmaak sodat aan sy tandvleis vasgestel kan word wat sy ras is. Anker word letterlik verdierlik: hy word soos 'n skaap behandel.

Die kroegtoneel verteenwoordig 'n emosionele knooppunt in die verloopsplan. Daarom is dit gepas dat die eerste bedryf daarmee eindig. Die spesifieke emosionele momentum wat

\footnotetext{
9 Dit wil nie sê dat Die koggelaar 'n volwaardige allegorie is nie. Desnieteenstaande vertoon dit sterk allegoriese trekke, onder andere in die obsessionele én dualistiese wyse waarop die hoofkarakter optree (vergelyk Fletcher, 1982:220 en verder). Daar word dus hoogstens van die allegoriese werkwyse gebruik gemaak.

${ }^{10}$ Vergelyk oor die rol van aansteeklike magie in die allegorie, Fletcher (1982, hoofstuk 2).
} 
hierdie toneel aan die handelingsverloop verskaf, word egter nie genoegsaam in die tweede toneel opgevolg nie. Daar is wel aan die einde van die drama die finale bevestiging dat Anker en Boet halfbroers is (bladsy 56 en verder, en veral bladsy 59), maar daar is terselfdertyd deur die teks prospektiewe speelhandelinge wat na hierdie onthulling heenwys. Ten opsigte van die onthulling van hul verwantskap speel die kroegtoneel dus geen beduidende rol nie, maar dra dit eerder tot dramatiese ironie by. Deurslaggewend ten opsigte van dramatiese ironie is dit nie, aangesien dié ironie (Boet en Anker se verwantskap) feitlik op elke bladsy voorkom.

In die kroegtoneel gaan dit om diskriminerende optrede op grond van ras. Vir die getal bladsye wat aan die kroegtoneel afgestaan is, naamlik agt (bladsy 25 tot 32), vervul dit nie 'n groot genoeg funksie nie.

'n Ander droogte in die gemeenskap, wat prominent uitgelig word, is die rol wat 'n persoonlike oortuiging in die lewe van kerkmense speel. Sy bynaam dui Daan spesifiek as 'n diaken aan. Nieteenstaande die feit dat sy naam hom as ' $n$ allegoriese personasie met bepaalde eienskappe merk, tree hy teen die normale verwagting van 'n diaken op. Daan se optrede moet egter teen die agtergrond van die hele handelingsverloop beoordeel word. Hy staan teenoor Boet, in so 'n mate dat Boet hom selfs te lyf gaan. Máár, eintlik is hulle voëls van eenderse vere: Daan sê prontuit wat hy dink en voel, terwyl Boet sy gevoelens verberg terwyl dit finansieel met hom goed gaan. Die satiriese strekking ten opsigte van hierdie situasie is dus nie teen die kerk gerig nie, maar teen persone in die gemeenskap wat dubbele standaarde handhaaf ter wille van eie gewin. Wanneer dit met Boet sleg begin gaan, verloor hy, nes Daan, sy geloof.

\section{Huwelik}

Nog 'n droogte, wat uit die teks afgelei kan word, is die droogte in Ben se huwelik. 'n Uiterlike teken daarvan is die swart trourok wat Anna na die biddag vir reën aantrek. 'n Verdere aanduiding van die metafisiese aard van die droogte tydens hierdie handelingsgeheel, is Boet se tipering van Anna as "duiwelsbruid" (bladsy 43). In sy verwarde toestand kon hy nie insien dat sy simbolies rou oor die verbrokkeling van hulle huwelik nie. Tydens ' $n$ herstellende fase ${ }^{11}$ van die beweging van libido verduidelik Anna aan hom (bladsy 50): "Ek het gesweer ek trek nie weer dié rok uit voor jy nie weer my man is nie." Die herstel was egter tydelik, want net daarna (bladsy 51) maak Klein-Ben weer 'n droomverskyning en neem die waansin toe.

Soos in Van Wyk Louw se Berei in die woestyn, is die afwesigheid van liefde onderliggend aan die droogtes, veral in figuurlike sin, in Die koggelaar. Die afwesigheid van 'n tans lewende kind dui dramaties op die afwesigheid van liefde in Boet en Anna se huwelik. Die afwesigheid van liefde is egter nie 'n probleem wat met die dood van Klein-Ben ontstaan het nie. Dit was van die begin van hul huwelik vir Boet belangrik om 'n erfgenaam te hê

\footnotetext{
${ }^{11}$ Hierdie verwysing is na die fase van progressiewe beweging van libido. Vergelyk Fordham (1975:18): -Jung calls the forward movement which satisfies the demands of the conscious, progression, the backward movement, satisfying the demands of the unconscious, regression. Progression is concerned with the active adaptation to one's environment, and regression with the adaptation to one's inner needs."
} 
(bladsy 6). Daarop dui ook die hartelose (liefdelose) wyse waarop hy Anna in die veld laat ten einde sogenaamde gunstige toestande vir konsepsie te skep.

Anna beleef die droogte van die afwesigheid van 'n kind op ' $n$ ander manier as Boet. Laasgenoemde word deur Betta verwoord (bladsy 13):

Skaars vyf́-en-dertig en jy's droog ... soos die grond, die damme ... En elke dag wét jy van jouself: 'n uitskot-ooi. Elke keer as jy die huis instap, dra jy die droogte oor jou drumpel ... kombuis toe ... eetkamer toe ... bed toe.

Betta se woorde, dat Anna 'n "uitskot-ooi" is, met ander woorde dat sy nie weer ná KleinBen kinders sou hè nie, word bevestig deur Anker se woorde op bladsy 14 ("Daar's ooie ook wat vrek ... van verdriet") en Boet se erkenning van skuld op bladsy 24. Biologies is Anna wel in staat om kinders in die wêreld te bring, want die teks stel dit duidelik dat Boet se saad versterk moet word (bladsy 40 en 46). Hy dra die skuld vir hul huidige kinderloosheid. 12

\section{Die veldtoneel}

'n Vraag waarop 'n antwoord gevind moet word, is of die veldtoneel 'n funksionele onderdeel van die drama as 'n geheel vorm. Dit bring terselfdertyd die vraag na die nodigheid van die gepaardgaande naaktoneel na vore. Om hierdie vrae te beantwoord, moet vasgestel word of die veldtoneel binne die verloopsplan ${ }^{13}$ van die drama val.

Dit wil voorkom of die veldtoneel gedeeltelik buite die verloopsplan lê. Vanweë die episodiese aard van die handelingsgehele is daar nie 'n lang aanloop tot dié toneel nie. In plaas daarvan dat die plek wat die veldtoneel in die verloopsplan inneem deur sy fisiese aanloop en afloop bepaal word, speel die aanloop en afloop van innerlike handeling die bepalende rol. As sodanig is die veldtoneel 'n demonstrasie van die mate waarin Boet sy aanraking met die werklikheid verloor het - en val dit dus binne die verloopsplan.

Dit is nie duidelik waarom dié toneel juis in die veld moet afspeel nie. Sodat Anker op Anna kan afkom? Maar is Anker se betrokkenheid in hierdie geval nodig? Bring die dramaturg Anker se betrokkenheid nie reeds funksioneel genoeg oor nie? Verder: dit wil voorkom of die gevolg van hierdie toneel op Anna te min aandag kry. Dit is, met ander woorde, sielkundig nie oortuigend genoeg verdiskonteer nie. Dit wil, in hierdie verband, voorkom of die kollig in die drama té skerp op Boet val.

Soos dié aanvang van die sentrale boorgattoneel, met sy verwysings na die Christelike nagmaal, vertoon die veldtoneel 'n rituele inslag. Dit word vir Boet en Anna 'n tweede

\footnotetext{
${ }^{12}$ Hierdie verduideliking sluit aan by 'n verdere betekenis van die titel. Nie net is Boet God se koggelaar nie, maar hy is ook 'koggelram'. Die WAT (1976, s.v. koggelram) verduidelik die betekenis van dic woord soos volg: "(Skaap- of bok)ram, gew. ongeskik vir teeldoeleindes, wat gesteriliseer (gevasektomiseer) is, maar nie gekastreer nie, en gebruik word om aanteelooie in 'n kudde te koggel ... ". Waarom Boct vir Klein-Ben kon verwek, maar 'n tweede kind nie, is nie uit die teks duidelik nie. Kyk verder 6, onder.

${ }^{13}$ Vergelyk Van der Kun (1938:12): "Het verioops-plan is een 'plan tot handelen' bij den acteur, en de toeschouwer wordt er door 'aangezet' en tot 'inzicht', tot 'verwerven' van een weten omtrent den gang van zaken."
} 
'huweliksnag', maar as gevolg van die werking van ironie ${ }^{14}$ verloop die situasie omgekeerd. In teenstelling met Ben, wat op bladsy 16 aan die begin van die boorgattoneel "die diepte van die Here se genade" noem, maak Boet op sy eie inisiatief staat: hy weier om van mediese hulp gebruik te maak en gebruik eerder 'n temperatuurkaart (bladsy 36). 'n Ooreenkoms tussen die boorgattoneel en die veldtoneel is dat in beide iets besweer word. In eersgenoemde is dit die "bose" wat "met God's gawe" besweer moet word (bladsy 19); in laasgenoemde moet die son "ons geluk besweer" (bladsy 37). Alhoewel daar dus in beide tonele sprake is van "besweer", verskil die fundamentele instelling van die betrokkenes. Die veldtoneel is daarom nóg 'n illustrasie van Boet se trots en sy toenemende 'blindheid'. Dit is duidelik uit sy woorde aan Anna op bladsy 38:

ANNA: Asseblief, laat my my skaamte bedek.

BOET: Jó́ skaamte? Dis myne. Die mense lag ... almal ... die wêreld lag my uit. En dis jy! Jy kan my nie 'n kind gee nie!

Teen hierdie tyd weet ons dat Boet nie in staat was om nog 'n kind te verwek nie.

Een aspek van die verskil in fundamentele instelling by Boet is sy geloof aan die genesende krag van die son (bladsy 38: "Die son sal jou genees"). Sy instelling is, in vergelyking met die begin van die boorgattoneel, nie-Christelik. Sy opvatting, dat die son Anna sal genees, moet gelees word teen die agtergrond van die vrugbaarheidsrituele waaruit die eerste vorme van die drama gegroei het (vergelyk Harrison, 1951). Ook Cirlot (1962) ${ }^{15}$ erken die simboliese aard van die son as "solar 'passion". Deur van hierdie verwysingsraamwerk gebruik te maak, verleen die dramaturg 'n rituele, simboliese aard aan die veldtoneel.

Binne die verloopsplan is die funksie van die veldtoneel om die toenemende waansin in Boet se bestaan uit te beeld. Dit word gedoen deur Boet se optrede te kontrasteer met Ben se optrede aan die begin van die boorgattoneel. Binne hierdie verband word daar, teen die agtergrond van die rol wat vrugbaarheidsrituele in die historiese ontwikkeling van die drama in die algemeen gespeel het, van 'n besonder kragtige simbool gebruik gemaak. Daarom is dit opmerklik dat die simboliek van die son dramaties nie verder in die handelingsverloop van die teks geïntegreer is nie.

Daarteenoor is die gebruik van die son op ideële vlak as simbool wél verklaarbaar teen 'n psigoanalitiese agtergrond. Vergelyk, in dié bespreking, die verwysings na Jung se teorieë.

\footnotetext{
${ }^{14}$ Ironie, meer spesifiek inoniese visie, speel 'n rol in hierdie teks. Dit kom die duidelikste na vore in die ommekeer van rolle. Vir Boet word God die groot koggelaar (onder andere bladsy 42), maar Anker sê vir hom op bladsy 55 dat hy "God (wil) speel". Verder: tydens die biddag vir reën word Anna vir hom 'n "duiwelsbruid" (bladsy 43), hul tweede 'huweliksnag' is eintlik 'n 'huweliksdag'. Talle ironiese situasies (byvoorbeeld die kroegtoneel) ontstaan omdat Boet nie daarvan bewus is dat Anker sy halfbroer is nie.

${ }^{15}$ Veral Cirlot(1962:302 en 303). Vergelyk bladsy 303: They were also forcibly struck by the analogy between the daily disappearance of the Sun and the winter solstice ... . At the same time, there was, for the primitive, astrobiological mind, an essential connection between the Sun and Moon, analogous to that between heaven and earth. It is well known that, for the vast majority of people, the sky is symbolic of the active principle (related to the masculine sex and to the spirit), while the earth symbolizes the passive principle (cognate with the feminine sex and with matter); ... . And the same thing happens with the Sun and Moon: solar 'passion', so to speak, with its heroic and fierce character, clearly had to be assimilated to the masculine principle, and the pale and delicate nature of lunar light ... had to be classified as feminine. These equations are certainly not constant; but the exceptions do not invalidate the essential truth of this symbolism".
} 
Cirlot (1962:304) skryf in hierdie verband: "Another alchemic concept, that of ... the invisible essence of the celestial Sun which nourishes the inborn fire of Man ... is an early pointer to the way the astral body has latterly been interpreted by psychoanalysts, narrowing its meaning down to that of heat or energy, equivalent to the fire of life and the libido. Hence Jung's point that the Sun is, in truth, a symbol of the source of life and of the ultimate wholeness of man ... ". Teen die agtergrond van die rituele aard van die veldtoneel is die implikasie dat die son uiteindelik vir Boet 'n kind in die plek van KleinBen moet besorg.

\section{6. "(D)ie rykste taal in die Afrikaanse drama"}

Hough (1988) maak die stelling dat dié drama "van die rykste taal in die Afrikaanse drama" bevat. Die eerste spreekbeurt, naamlik Knaplat se woorde op bladsy 1, het 'n didaktiese strekking. Die kern van die eerste spreekbeurt lui soos volg:

Dan het die koggelmandervoet hom tog vertrap. Hier in ons kontrei is dit wet, 'n waarheid soos kaiingklip en muistepelbos: vertrap jy hom, vertrap hy jou. ... Boet Cronjé, jy moes dit geweet het. ... dis die slotsom van 'n leeftyd saam met Boet Cronje ... (my kursivering - JLC).

Die didaktiese strekking van die spreekbeurt is die slotsom waarna Knaplat verwys, naamlik dat die koggelmandenvet Boet tog vertrap het.

Die woord "koggelmandervoet" het 'n oordragtelike betekenis. Dat die woord nie letterlik verstaan moet word nie, word deur die disjunktiewe aanwending van die woord "vertrap" aangedui. As 'n vorm van metaforiese taalgebruik vertoon "koggelmandervoet", binne die konteks van die uiting, sinekdogeïese én metonimiese funksie. 16 'n Koggelmander se voet is maar een van sy vier pote, met ander woorde 'n deel wat sinekdogeïes 'n geheel verteenwoordig. Binne die konteks van hierdie uiting is genoemde geheel nie 'n ware koggelmander ('n reptiel behorende tot die familie Agamidae) nie, maar groei die konsep koggelmander algaande metonimies om alles in te sluit wat die kode koggel in die drama anafories aandui.

Binne die konteks van die betrokke spreekbeurt verwys die woord "koggelmandervoet", soos die woord "muistepelbos", ook na 'n plant. Die koggelmandervoet se takke lyk soos 'n koggelmander se voet (WAT, 1976, s.v. "koggelmandervoetkaroo" en Smith, 1966:303). Indien aanvaar word dat Boet Cronje, in die tweede helfte van die handelingsverloop, almal en alles om hom vertrap, kan die koggelmandervoet as verteenwoordiger van die natuur beskou word. Vergelyk in hierdie verband hoe Boet weier om die wateraar oop te boor en hoe plant en dier as gevolg van daardie besluit moet ly. Dit kom daarop neer dat

\footnotetext{
${ }^{16}$ Lees hicrdie stelling teen die agtergrond van die volgende woorde deur Eksteen (1971) en BrookeRose (1965). Eksteen (1971:20) verduidelik: "Op grond van 'n analise van die vergelyking en die metafoor, enersyds, en die empiriese gegewens met betrekking tot die grammatiese gedrag van 'n verskeidenheid stylfigure, andersyds, word die voorlopige gevolgtrekking gestel dat figure soos die personifikasie, sinekdogee, antonomasia, metonimia e.d.m. almal metafore is." In aansluiting daarby verklaar Brooke-Rose (1965:4): "Now metaphor is the chief of the tropes, but it is obvious even within the system of rhetoric that several tropes and even other figures can be combined in one metaphor ..." In die geval van Knaplat se woorde, "Dan het die koggelmandervoet hom tog vertrap", het ons 'n metafoor, wat tot stand kom as gevolg van die funksic wat onder andere sinekdogee en metonimia daarin vervul.
} 
die natuur op Boet 'wraak neem' en hom 'vertrap': omdat hy nie die water voorsien het wat hy kon nie, het hy algaande uitgeboer. ${ }^{17}$

Dit is veral die skaapram, Knaplat, se woorde wat Boet se misdrywe teen die natuur uitlig. So beskuldig hy Boet op bladsy 3 van selfsug: "Ons was een met hierdie grond, maar vir jou was ek iets om getap te word; die skaap met wie jy kon mak soos en wat jy wou. My hele bestaan was net vir jou." Nog feller is die aanklag op bladsy 12: "Wat weet jy van swart droogtes se seer? Seer lê nie net in jou oog of jou gemoed nie. Dié droogte pyn in my maag."

Dat Knaplat kan praat en in alle opsigte soos 'n mens optree, gee reeds 'n aanduiding van die mate waarin werklikhede in die drama deureenspeel. Voorbeelde van sodanige werklikhede is die werklikheid waarin Knaplat (WKnaplat), Anker (WAnker), Anna ( $W_{A n n a}$, Ben ( $\left.{ }^{W} B e n\right)$, Klein-Ben ( $\left.W_{K l e i n}-B e n\right)$ en Boet self ( $W_{B o e t}$ ) optree. Hierdie werklikhede verteenwoordig subwèrelde (vergelyk Elam, 1980, hoofstuk 4), wat 'n wisselende invloed op die handelingsverloop het. Die integrale wyse waarop elke subwereld sy funksie in die drama se plan vervul, dra daartoe by dat die totale dramatiese werklikheid vervreemdend inwerk. In hierdie opsig verraai Die koggelaar, soos Ek, Anna van $W y k$, op eiesoortige wyse die invloed van die epiese teater. Dit geld veral die wyse waarop die drama aspekte van die gewone werklikheid aanspreek.

Die woord "koggelmandervoet" hou verder, op grond van die gemene voorkoms van die woorddeel koggel-, met die titel verband. Op grond van die wyse waarop die kode koggel in die teks self optree, verwerklik dit die algemene woordeboekbetekenis van "iem. of iets wat koggel" (WAT, 1976, s.v. koggelaar).

\section{Ten slotte}

Dit is inderdaad die geval dat Die koggelaar plek-plek van die rykste taal in die Afrikaanse drama het en dat dié taalgebruik emosioneel is. Dit dra daartoe by dat die teks dramaties én opvoeringsgerig is. Dit is egter ook waar dat sommige sake in die handelingsverloop té bedag voorkom.

In hierdie verband kom Boet se selfmoord onbevredigend, selfs melodramaties, oor. Dit is nie 'n verrassing nie - waarmee bedoel word dat die slottoneel 'n ander funksie vervul as om 'n tevrede toeskouer, soos in 'n tradisionele Aristoteliaanse drama, huis toe te laat gaan. Die slottoneel buig terug na die openingstoneel, 'n werkwyse waarvan Fourie ook in Ek, Anna van Wyk en Die groot wit roos gebruik maak. Hierdie procédé lei daartoe dat Die koggelaar iets van 'n epiese onthullingsdrama word, wat van die toeskouer vereis om denkend saam met 'n 'verklarende' handelingsverloop te beweeg. Dit loop in die strategiese slottoneel daarop uit dat die klem nie op Boet se selfmoord val nie, maar op dié punchline (Anker se woorde, bladsy 61): "Nee, ek is nog daar."

\footnotetext{
${ }^{17}$ Die mate waarin die natuur 'vertrap' is, word weerspieël in die gehardheid van die koggelmandervoet. Smith (1966:303) skryf daaroor: "The plants are extremely drought resistant and tenacious of life. Much relished and usually closely grazed by stock and will withstand heavy grazing, but rapidly recovers when the veld is rested."
} 
Daarmee verskuif die fokus weg van die eb en vloed wat Boet se karakterisering tot dusver gekenmerk het, na die idee wat die drama wil oordra: dat die ondergeskikte die plek van die maghebber neem. 'n Totale vervanging van 'n ou met 'n nuwe orde is dit egter nie, want Boet en Anker het baie met mekaar gemeen. Hulle het onder andere dieselfde vader (Ben) en is halfbroers. Wil die dramaturg hiermee sê dat geen nuwe orde volkome nuut of anders kan wees nie? Wil hy se dat dieselfde 'droogtes' in Anker teenwoordig is as in Boet? Maar hoe skakel dit dan met die kroegtoneel?

Die skakeling met die kroegtoneel lê in die aandag wat daarin aan ras gegee word. In die slottoneel (bladsy 60) verf Boet die damvloer wit, en herhaal dan: "Wit soos ek!" In die nuwe orde, verteenwoordig deur Anker, sal daar nie plek wees vir rasseonderskeidings op grond van kleur nie. Daarom kan Knaplat, die personasie van 'n "swart akteur" (bladsy 1), in 'n simboliese gebaar (bladsy 61) van sy "wit draadmasker" (bladsy 1) ontslae raak (my kursivering - JLC).

Ongelukkig wil dit voorkom of die slottoneel té swaar dra aan die idee (ras). Dit kom daarop neer dat die idee nie genoegsaam deur die handelingsverloop voorberei word nie. Die klem het in die handelingsverloop té duidelik op Boet en sy droogtes geval om die idee in die slottoneel oortuigend genoeg te motiveer.

Die karakter, Boet Cronjé, mag wel in die Afrikaanse dramaliteratuur voortleef, maar dit sal nie wees as gevolg van volronde karakterisering nie. Daarvoor is sy geding met homself, met God, met sy huisgenote en met sy gemeenskap te enkelvoudig. Ook ontbreek dit hom aan innerlike en sosiale statuur om die droogtes om en in hom met verbeelding aan te pak. 'n Periandros of Germanicus (in die dramaliteratuur) of Bart Nel (in die prosaliteratuur) is hy nie. Sy aanspraak op voortbestaan mag spruit uit die onverbiddelike manier waarop hy op sy ondergang afstuur, en die feit dat hy aan die einde 'n mate van selfinsig openbaar.

\section{Literatuurlys}

Brooke-Rose, C. 1965. A grammar of metaphor. London : Mercury.

Cirlot, J.E. 1962. A dictionary of symbols. Translated from the Spanish by J. Sage. New York : Philosophical Library.

Eksteen, L.C. 1971. Die metafoor. Standpunte 94, 24(4):14-26.

Elam, K. 1980. The semiotics of theatre and drama. London: Methuen. (New Accents.)

Fletcher, A. 1982. Allegon: the theony of a symbolic mode. Ithaca : Cornell University Press.

Fordham, F. 1975. An introduction to Jung's psychology. Harmondsworth : Penguin.

Fouric, P. 1988. Die koggelaar. Pretoria : HAUM-Literêr.

Harrison, J.E. 1951. Ancient ant and ritual. Oxford : University Press.

Honig, E. 1982. Dark conceit: the making of allegory. Hanover : University Press of New England.

Hough, B. 1988. Fourie se drama is meesteriik. Insig : 44-45. Junie.

Louw, N.P. van Wyk. 1970. Berei in die woestyn: ' $n$ sinne- en wa-spel. Kaapstad : Tafelberg.

Muller, P., Du Preez, H., Scholtz, L. \& Van Rensburg, C. 1989. Die wolf in ons midde. Insig : 10-14. Jul.

Schutte, H.J. 1989. Ontgrensing en verruiming van die Afrikaanse drama in die tagtigerjare. Tydskrif vir Letterkunde, 26(4):76-88.

Smith, C.A. 1966. Common names of South African plants. Edited by E.P. Philips \& E. van Hoepen. Pretoria: Government Printer. (Botanical Research Institute: Botanical Survey Memoir, no. 35.)

Van der Kun, J.I.M. 1938. Handelingsaspecten in het drama. Nijmegen : Berkhout. 
Van Melle, J. 1977. Bart Nel. Pretoria : Van Schaik.

Van Rensburg, P. 1989. Pieter Fouric: Die koggelaar. South African Theatre Joumal, 3(2):123-125.

Verklarende Afrikaanse Woordeboek, bewerk deur M.S.B. Kritzinger, F.J. Labuschangne \& P. de V. Pienaar. 1972. S.v. allegorie. Pretoria : Van Schaik.

Woordeboek van die Afrikaanse Taal, deel 6. 1976. S.v. kogelaar, koggelmandervoetkaroo \& koggelram. Pretoria : Staatsdrukker.

\section{Universiteit van Suid-Afrika}

